\title{
DIETRICHA VON HILDEBRANDA KONCEPCJA POZNANIA WARTOS̄CI MORALNYCH
}

Przedmiotem niniejszych analiz będzie zagadnienie związku pomiędzy statusem moralnym osoby ludzkiej a możliwością i zakresem poznawania przez nią wartości moralnych. O istnieniu tego związku uczy nas już potoczne doświadczenie. Mówi nam ono np., że poprzez ciągłe realizowanie pewnych antywartości moralnych ktoś może przestać dostrzegać odpowiednie wartości. Kto stale kradnie może stać się ślepy na wartość poszanowania cudzego mienia. Odwrotnie, kto realizuje pewne wartości, stając się przez to człowiekiem cnotliwym, ten w danej dziedzinie moralności posiadał będzie szczególnie wyostrzone spojrzenie aksjologiczne. Człowiek prawdomówny będzie wyczulony na antywartość każdego, nawet najdrobniejszego kłamstwa. Istnieje niewątpliwie ścisły związek pomiędzy bytem moralnym człowieka a zdolnością postrzegania przez niego wartości. Jakiego rodzaju jest to związek? Czy ktoś czyni zło i staje się zły moralnie dlatego, że nie widzi wartości, czy też odwrotnie, ktoś nie dostrzega wartości dlatego, że jest zły moralnie? Jak wiadomo, Sokrates przyznał w moralności priorytet poznaniu nad cnotą. Według jego koncepcji poznanie wartości - by posłużyć się terminologią filozofii współczesnej — jest fundamentem moralności człowieka, i to $\mathrm{w}$ ten sposób, że jest nie tylko jej warunkiem koniecznym, lecz zarazem wystarczającym. Arystoteles przyznając Sokratesowi częściową słuszność zauważył jednak, że niepodobna być rozsądnym moralnie bez posiadania cnoty ${ }^{1}$, czyli że nie można osiągnąć w dziedzinie etycznej należytego poznania, bez wcześ-

1 Por. Arystoteles, Etyka nikomachejska (tłum. D. Gromska), Kraków 1956, VI, 1144b, 31, Zob. też: D. von Hildebrand, Sittlichkeit und ethische Werterkenntnis, [w:] Jahrbuch für Philosophie und phänomenologische Forschung, t. V, Halle 1921, s. 463-602, tutaj s. 463-464. Studium to oznaczymy skrótem SEW. Dla innych pism von Hildebranda używać będziemy w niniejszym artykule następujących skrótów:

Ae1 - Asthetik, 1. Teil, Stuttgart 1977.

E - Ethik, Stuttgart 1973.

IG - Idolkult und Gotteskult, Regensburg 1974.

ISH - Die Idee der sittlichen Handlung, [w:] Jahrbuch für Philosophie und phänomenologische Forschung, t. III, Halle 1916, s. 126-251.

M - Moralia, Regensburg 1980.

SKS - Situationsethik und kleinere Schriften, Stuttgart 1973.

WL - Das Wesen der Liebe, Regensburg 1971.

WPh - Was ist Philosophie, Stuttgart 1976.

29 - Analecta Cracoviensia 
niejszej realizacji wartości moralnych. Tak więc poznanie wartości zakładałoby pewien fundament moralny w bycie osoby, zaś fundament ten mógłby być położony jedynie pod warunkiem poznania wartości. Czy nie wchodzimy tutaj w błędne koło?

Jeślibyśmy poznanie wartości i moralny byt osoby ludzkiej rozpatrywali w sposób globalny, to istotnie nie istniałaby żadna możliwość uchronienia się przed wpadnięcie w błędne koło i wydostania się $\mathrm{z}$ niego. Dlatego zagadnienie to należy rozpatrzyć w sposób zróżnicowany, w optyce różnych sposobów poznania wartości i różnych poziomów moralnego bytu człowieka. Tak właśnie czyni to von Hildebrand. Podążmy zatem jego śladem.

\section{SPOSOBY POZNANIA WARTOSCI}

Zasadniczym sposobem poznania wartości jest ich ujęcie intuicyjne, które w terminologii von Hildebranda przybiera nazwę ,uchwycenia wartości” (Werterfassen) ² czy ,ujęcia poznawczego wartości” (Wertkenntnisnahme) ${ }^{3}$. Ujęcie takie jest szczególną formą postrzeżenia (Wahrnehmung); posiada bowiem wszystkie istotne cechy, jakie należą do postrzeżenia w ogóle, a więc: realną obecność przedmiotu, ,zapładniający” kontakt przedmiotu $\mathrm{z}$ podmiotem, intuicyjny charakter tego kontaktu ${ }^{4}$. Bezpośrednie ujęcie poznawcze wartości może przybrać jedną $\mathrm{z}$ następujących dwu form: „widzenie wartości” (Wertsehen) lub „czucie wartości” (Wertfühlen) ${ }^{5}$. Różnicę pomiędzy widzeniem a czuciem uwyraźnić można na przykładzie wartości estetycznych. Oglądając jakieś dzieło sztuki czy krajobraz mogę ,widzieć" jego piękno, jednakże bez żadnego wewnętrznego „czucia” go, tak jak to np. jeszcze wczoraj mogło być moim udziałem. Ten sam stan rzeczy odnosi się również do wartości moralnych. Von Hildebrand wyróżnił nawet dwie formy czucia: „wniknięcie w wartość”, które mutatis mutandis - można porównać do smakowania potrawy, oraz „wniknięcie wartości we mnie”, które z kolei można przyrównać do przenikającego mnie bólu ${ }^{6}$. Dopiero w czuciu wchodzimy w żywotny i twórczy kontakt z wartością. Czucie, przy jednakowym stopniu wyrazistości danej w nim wartości, może różnicować się pod względem głębi. O wiele głębiej czuje wartości moralne człowiek święty, aniżeli człowiek, który wprawdzie otwarty jest na świat wartości i rozumie go, ale ,nie grzeszy świętością". Nieskończonej głębi wartości moralnych odpowiada bowiem

2 Por. ISH, s. $143 ; E$, s. 240.

8 Por. SEW, s. 467.

4 Por. WPh, s. $159-162$; Ae1, s. $350-351$.

5 Por. SEW, s. 469.

6 Por. SEW, s. 470. 
nieskończona gradacja w czuciu i rozumieniu tych wartości ${ }^{7}$. Już przy pierwszym wejrzeniu staje się też jasne, że im wyższy jest stopień posiadanej cnoty moralnej, tym głębsze i bardziej adekwatne staje się czucie odpowiedniej wartości.

Intuicyjne uchwycenie wartości w pewnej konkretnej sytuacji nie jest jedyną formą kontaktu poznawczego człowieka $\mathrm{z}$ wartościami. Istnieje także intuicyjna znajomość (intuitives Kennen) wartości ${ }^{8}$, która umożliwia stałą, ponadaktualną relację już nie do wartości konkretnej, lecz do pewnego typu wartości. Możemy tu pomyśleć np. o człowieku, który w obliczu jakiegoś rażącego skąpstwa uchwyci wartość hojności, nie posiada on jednak jeszcze $\mathrm{w}$ stosunku do niej stałego odniesienia poznawczego. Kto z n a wartość hojności, ten nie musi uczyć się jej za każdym razem od nowa w konkretnych sytuacjach, ten może przedstawić sobie jej istotę bez potrzeby uciekania się do doświadczenia jakiegoś hojnego czynu. Znajomość taka różna jest od teoretycznej wiedzy (Wissen) o wartości; wiedza nie posiada elementu intuicyjnego kontaktu $\mathrm{z}$ wartością. Ktoś np. wie - tylko wie - z katechizmu, że pokora chrześcijańska jest postawą o wysokiej wartości moralnej, jednakże wartości tej sam nigdy naocznie nie uchwycil i nie zna jej.

Jak więc wiảać istnieją rozmaite formy kontaktu poznawczego $\mathrm{z}$ wartościami; różnie zatem będą się kształtowały wzajemne związki pomiędzy poznaniem a jego fundamentem moralnym w człowieku. W tej sytuacji, paradoksalnie, wiele światła na istotę tych związków może rzucić analiza fenomenu ślepoty na wartości.

\section{SLEPOTA NA WARTOSCI}

Bywają ludzie, którzy w obliczu wartości moralnych pozostają tak niewrażliwi jak ludzie niemuzykalni wobec piękna jakiejś melodii. Ślepota $\mathrm{w}$ dziedzinie moralnej może odnosić się do pewnych tylko typów wartości, bądź też do całej ich sfery, przy czym im wyższa wartość moralna wchodzi w rachubę, tym częstsze bywają wypadki ślepoty ${ }^{9}$. Jednakże nawet najbardziej rozpowszechniona ślepota co do pewnego typu wartości moralnych nie upoważnia nas do wyrokowania o jakiejś ,niemożności organicznej” czy braku ,,talentu moralnego”. To, że widzenie i czucie wartości moralnych nie jest związane $z$ jakimś szczególnym uposażeniem duchowym człowieka, można zauważyć w przypadku nawrócenia, kiedy to ktoś, kto dotychczas pozostawał ślepy przynajmniej na niektóre wartości moralne, nagle zaczyna je dostrzegać w całej ich wy-

7 P.or. SEW, s. 471.

8 Por. SEW, s. 473.

9 Por. SEW, s. 483. 
razistości i ze wszystkimi ich wymogami. Sytuacja takiego nagłego nawrócenia jest nie do pomyślenia $w$ sferze wartości estetycznych, których percepcja zakłada - przynajmniej w pewnej mierze - jakiś właśnie wrodzony talent.

Von Hildebrand wyróżnia kilka rodzajów ślepoty na wartości. Omówmy je kolejno.

\section{Slepota subsumcji}

Ślepota tego rodzaju polega na niemożności widzenia wartości (lub antywartości) w pewnej konkretnej sytuacji, a dokładniej, na niezdolności do podciągania pewnego konkretnego zachowania czy postawy wcielającej wartość (lub antywartość) pod ogólny i znany już typ wartości (lub antywartości). Należy tutaj uwypuklić dwie rzeczy: a) w ślepocie subsumcji nie chodzi o świadomą niechęć do uznania wartości już rozpoznanej; b) nie chodzi tutaj również o niewidzenie pewnego typu wartości jako takiego. Przeciwnie, ktoś kto zna wartość sprawiedliwości, w jakiejś sytuacji może jej wcale nie zauważyć.

Istnieją rozmaite faktory zaciemniające wzrok aksjologiczny. Jednym z nich, szczególnie wpływowym, jest „wabienie” płynące ze strony korzyści własnej i tego co zmysłowo - w najszerszym tego słowa znaczeniu - przyjemne; faktor ten w opisie von Hildebranda otrzymuje, w nawiązaniu do doświadczenia Odyseusza, poetycką nazwę ,syreniego śpiewu” ${ }^{10}$. „Syreni śpiew” może skutecznie przytępić wrażliwość na rzeczywiste wartości, a ukonstytuować natomiast wyimaginowane wartości tam, gdzie ich nie ma. Do tego rodzaju złudzenia dochodzi wtedy, gdy ,syreni śpiew" instynktów, popędów, skłonności itd., napotyka na korzystny dla siebie subiektywizm sumienia, które bezgranicznie sobie ufając zdaje się zawsze na nieomylność własnych mniemań.

Od tego złudzenia odróżnić należy zaślepienie przez namiętność, które sprawia, że ktoś nie dostrzega antywartości własnego postępowania. Tak np. mężczyzna żonaty, który w wierności małżeńskiej widział zawsze wysoką wartość, zakochując się w innej kobiecie i zrywając więzy z żoną nie dostrzega teraz antywartości własnej niewierności. Jest on raczej skłonny uważać swoje postępowanie za ,przypadek szczególnego rodzaju”, aniżeli uznać zło i winę. Sama namiętność jako taka nie rodzi jeszcze ślepoty na wartości czy antywartości; co więcej, walka z nią może wyostrzyć wzrok aksjologiczny. Ażeby doszło do zaślepienia, namiętność musi zapanować nad osobą natrafiającą w niej na sprzyjającą temu zaślepieniu postawę nieświadomego unikania wszelkich konfliktów pomiędzy

\footnotetext{
10 Por. SEW, s. 488.
} 
wymaganiami moralnymi a osobistymi skłonnościami. Niewątpliwie kryje się $w$ tej postawie swego rodzaju szacunek dla sfery etycznej (bez niego mielibyśmy do czynienia z cynicznym poddaniem się namiętnościom przy równoczesnym dostrzeganiu antywartości własnego postępowania), ale zarazem jest też w niej otwartość na wszystko to co przyjemne, brak zdecydowania na wyrzeczenie się zadowolenia, jeśli wiązałoby się ono $\mathrm{z}$ antywartością moralną ${ }^{11}$. Poddanie się namiętności, podobnie jak tendencja do unikania konfliktów moralnych, posiada charakter nieświadomy, albo lepiej: nieuświadomiony ${ }^{12}$. Dominacja zaś rozmaitych faktorów zaślepiających ma miejsce w głębszej sferze osoby ludzkiej aniżeli sfera aktualnego postrzegania wartości.

\section{Ślepota przez otępienie}

Tego rodzaju ślepota na wartości wykazuje pewne podobieństwo do ślepoty subsumcji, jednakże podczas gdy ślepota subsumcji dotyczy zarówno widzenia jak i czucia wartości, to ślepota spowodowana przez otępienie odnosi się w pierwszym rzędzie do czucia. Doświadczenie mówi nam, że kto często popełnia jakiś zły czyn, ten z biegiem czasu może stać sie niewrażliwy na jego antywartość. Dochodzi wtedy bowiem do otępienia sumienia, a później - stopniowo - do przytępienia czucia i widzenia wartości. Warunkiem koniecznym do zaistnienia ślepoty przez otępienie jest, oprócz często powtarzanej złej czynności, pewna dwuznaczna fundementalna postawa moralna człowieka, który wprawdzie chce unikać zła, ale w sposób ograniczony, z zastrzeżeniami ${ }^{13}$.

\section{Ślepota częściowa}

Istnieją ludzie, którzy są całkowicie ślepi na pewne wartości czy cnoty moralne. Jeśli w ślepocie subsumcji mieliśmy do czynienia z niezdolnością do uchwytywania wartości w konkretnych sytuacjach, to tutaj chodzi już o niewidzenie całego typu wartości. Np. ktoś, kto wyraźnie

11 Por. SEW, s. $491-492$.

12 Czym jest tego rodzaju nieświadomość? Von Hildebrandowi nie chodzi tutaj o nieświadomość jako przeciwieństwo tego, co „aktualnie świadome”. Jeśli jakieś przeżycie, np. intensywnego bólu głowy, wypełnia całą świiadomość aktualną, to nie znaczy, że inne rzeczywisitości duchowe, np. miłość do drugiej osoby, stają się przez to nieświadome. Miłość taka posiada raczej charakter ponadaktualny. Nieświadomymi są natomiast te nastawienia, postawy czy nawet akty, które zostają rozpoznane i uświadomione w ich własnej identyczności. Tak np. ktoś może kochać drugą osobę bez wyraźnego zdania sobie z tego sprawy. Uświadomiwszy sobie tę miłość, daje jej tym samym nowy spasób istnienia, świadomy, nie zawsze jednak aktualny (por. SEW, s. 494-497).

13 Por. SEW, s. 504. 
dostrzega wartość sprawiedliwości, może zupełnie nie widzieć wartości czystości. Istnieje wiele różnorakich form częściowej ślepoty na wartości; wszystkie one rodzą się - przy nieuświadomionym wpływie pychy i pożądliwości — z braku bezwarunkowego oddania się realizacji podstawowej wartości dobra moralnego ${ }^{14}$. Von Hildebrand zauważa, że pycha i pożądliwość mogą działać również pośrednio, np. poprzez przeakcentowanie doniosłości wartości pozamoralnych ${ }^{15}$. Dla przykładu, egzaltacja wartości intelektualnych może zniekształcić widzenie wartości moralnych i właściwej im doniosłości.

\section{Ślepota totalna}

Istnieją też ludzie - zdaniem von Hildebranda - pozbawieni jakiegokolwiek rozumienia dobra i zła moralnego. Pojęcia ,dobro” i ,zło” są dla nich niemal tak samo puste jak dla człowieka niewidomego pojęcia ,czerwień" i ,zieleń" ${ }^{16}$. Ktoś dotknięty ślepotą totalną w przypadku przebiegłej niesprawiedliwości będzie może podziwiał przebiegłość nie dostrzegając samej niesprawiedliwości.

Istnieją dwa podstawowe typy tej ślepoty: „ślepota obojętności” i ,ślepota wrogości"; najczęściej są one ze sobą powiązane. Obojętność w pierwszym typie ślepoty nie jest świadomie obraną postawą wobec wartości, nie jest negatywną odpowiedzią na świat wartości moralnych. Jest raczej czysto obiektywnym stosunkiem do tych wartości, zawartym w nieograniczonym otwarciu się na wszystko to, co subiektywnie zadowalające ${ }^{17}$. W ,ślepocie wrogości" mamy do czynienia z nienawiścią skierowaną ku wszystkim wartościom moralnym. Co prawda, są one tutaj w pewien sposób postrzegane, ale tylko formalnie, tzn. o tyle, o ile przedstawiają dla postrzegającej je osoby zagrożenie w jej nieograniczonej autonomii ${ }^{18}$. Źródłem ,ślepoty obojętności” jest pożądliwość (Begehrlichkeit), natomiast ,ślepotę wrogości" rodzi pycha (Hochmut) ${ }^{19}$.

Wyróżnienie tych różnych rodzajów ślepoty na wartości, oprócz ukazania możliwości rozwiązania problemu postawionego na początku niniejszych analiz odsyła nas do pewnych danych antropologicznych, istotnych dla refleksji etycznej. Oto bowiem u źródeł ślepoty na wartości leżą negatywne $\mathrm{z}$ moralnego punktu widzenia czynniki, stale obecne i działające we wnętrzu człowieka. Ażeby lepiej zrozumieć ich funkcjonowanie, spróbujmy dokładniej je opisać.

\footnotetext{
14 Por. SEW, s. 506.

15 Por. IG, s. 26-27.

16 Por. SEW, s. 485.

17 Por. WL, s. 33; SEW, s. 521.

18 Por. $E$, s. 456 ; $M$, s. 242.

19 Por. SEW, s. 518-519.
} 


\section{TRZY OSRODKI W CZŁOWIEKU}

Istnieją akty osobowe, które wykluczają się wzajemnie z racji swojej natury bycia-odpowiedzią na coś pozytywnie lub negatywnie doniosłego. Tak $\mathrm{np}$. nie mogę $\mathrm{w}$ obliczu tego samego przedmiotu być zarazem oburzony i oczarowany. Niekoniecznie jednak wymagana jest obecność tego samego przedmiotu w tym samym czasie, ażeby można było uchwycić dysonans pomiędzy niektórymi aktami ludzkimi. Tak np. niewyobrażalna jest sytuacja, w której ktoś wielkodusznie przebacza doznaną krzywdę, a rơwnocześnie planuje zemstę wobec kogoś innego. Można by nawet przypuścić, że tak radykalnie, jakościowo różniące się pomiędzy sobą akty zakładają jakieś dwa różne, ,ja" obecne w człowieku ${ }^{20}$.

Fenomenowi niezgodności jakościowej aktów przeciwstawia się fenomen ich podobieństwa. Tak np. dobrze harmonizują z sobą akty wielkoduszności, przebaczenia, szacunku, pokory, itd. Obydwa te fenomeny pozwalają von Hildebrandowi na wyróżnienie trzech ośrodków w człowieku; dwóch negatywnych: ,pycha” i ,pożądliwość”, oraz jednego pozytywnego: ,,ja miłujące” ${ }^{21}$. Ośrodki te nie są jakimiś konstytutywnymi „,częściami” bytu osoby ludzkiej czy też „władzami" jej duszy; są raczej pewnymi jakościowo różniącymi się pomiędzy sobą jednościami fundamentalnych postaw i wypływających $\mathrm{z}$ nich aktów ${ }^{22}$.

\section{„Ja pyszne” $i$ „ja pożadliwe”}

Resentyment, nienawiść, pragnienie zemsty, itd., wskazują na swoje wspólne źródło: ,,ja pyszne”. „Ja pożądliwe” przejawia się np. w zachłanności, sknerstwie, nieczystych pragnieniach, itd. W filozoficznej refleksji von Hildebranda pożądanie jest nie tylko ową zniewalającą człowieka siłą, która ,z grzechu pochodzi i do grzechu prowadzi” ${ }^{23}$. Sama w sobie jest już złem moralnym, zdolnym ogarnąć całą osobę, aż po najwyższe sfery jej ducha.

W tych dwóch negatywnych ośrodkach von Hildebrand upatruje korzenie całego zła moralnego człowieka ${ }^{24}$. Mogą one oddziaływać zarówno pojedynczo, jak i we wzajemnym powiązaniu, przejawiającym się jako jedyne ,ja pyszne i pożądliwe” ${ }^{25}$. Dodać można, że o ile — zdaniem von Hildebranda — daje się pomyśleć istnienie bytu osobowego przenikniętego

20 Por. SEW, s. 583.

21 Por. SEW, s. $584 ;$ E, s. 425.

22 Por. E, s. 426.

23 Por. K. R a hiner, Zum theologischen Begriff der Konkupiszenz, [w:] Id., Schriften zur Theologie, t. I, Zürich-Köln 1954, s. 377-414.

24 Por. SEW, s. 589.

25 Por. SKS, S. 283. 
tylko pychą, o tyle nikt nie staje się pożądliwy bez udziału pychy ${ }^{26}$. Pycha odnosi się do sfery bycia osoby; jest swego rodzaju „zatrutym” ustosunkowaniem się do własnej doskonałośai. Pożądliwość natomiast ma za przedmiot sferę posiadania ${ }^{27}$.

„Ja mitujace”

$\mathrm{Na}$ przeciwległym biegunie do ,,ja pysznego i pożądliwego”, aczkolwiek nie na tym samym poziomie, sytuuje się ,ja miłujące”, źródło dobra moralnego ${ }^{28}$. To ,„ja" daje się szczególnie łatwo zauważyć w przypadkach nawrócenia. Kiedy jakiś zbrodniarz będąc świadkiem czyjegoś przebaczenia, radykalnie odmienia swoje życie, to mamy wówczas do czynienia nie tylko z pojedynczym dobrym moralnie aktem, lecz z narodzeniem się nowego człowieka, z wynurzeniem się ,,ja miłującego”. Również w przypadkach nawróceń mniej lub bardziej efemerycznych oddziaływać musi owo źródło dobra. Nie istnieje bowiem żadne spontaniczne przejście np. od pragnienia zemsty do wielkodusznego przebaczenia, tak jak istnieje ono choćby w kolejnym przeżywaniu przygnębienia i pogody ducha.

Wszystkie trzy ośrodki, trzy ,,ja”, koegzystują ze sobą wpływając w rozmaity sposób na życie moralne człowieka. Przypatrzmy się teraz kilku typowym ich konfiguracjom ${ }^{29}$.

Konfiguracje ośrodków

,Człowiek walczący” jest stanowczo zdecydowany poddać się wszystkim wymogom wartości; nierzadko prowadzi on ciężkie boje o to, by zdominować w sobie pychę i pożądliwość. Charakterystyczną cechą człowieka tego typu jest stała wola realizacji dobra moralnego.

„Człowiek nieświadomy" nie zajmuje żadnego określonego i zdecydowanego stanowiska w sprawach moralnych. Zarówno jego odpowiedzi na wartości jak i ustępstwa czynione pysze i pożądliwości noszą znamię przypadkowości, poddania się impulsom chwili ${ }^{30}$. Trzy ośrodki koegzystują w nim ,pokojowo”, bez żadnych konfliktów czy dramatów moralnych.

„Człowiek kompromisu", w przeciwieństwie do ,człowieka nieświadomego", zna w pewien sposób wartości i ich wymogi. Jeśli z jednej strony stara się nie popaść $\mathrm{w}$ otwarty konflikt $\mathrm{z}$ nimi, to $\mathrm{z}$ drugiej nie angażuje się całkowicie na ich korzyść szukając jakiejś drogi pośredniej. Z łat-

\footnotetext{
26 Por. E, s. 447.

27 Por. E, s. 426.

28 Tamże.

29 Por. E, s. 428.

30 Por. E, s. 275.
} 
wością staje się on posłuszny głosowi pychy i pożądliwości ${ }^{\text {s1 }}$. Jest człowiekiem, który chce służyć dwom panom.

,Sługa idola” wynosi na miejsce wartości absolutnej jakieś dobro pozbawione takiej doniosłości, jak np. państwo czy rasę, a nawet postępuje tak z antywartością. W tym ostatnim wypadku jest już rzeczą niemożliwą mówić o jakiejś koegzystencji ośrodków. Sługa idola może być jednak zagorzałym ,idealistą”, zdolnym do poświęcenia się ,,sprawie”. W jego oddaniu się ideowi zawiera się jakaś pseudo-odpowiedź na wartość, wraz z domieszką zamaskowanej pychy. „Sługa idola” nie stara się oszukiwać innych; oszukuje sam siebie ${ }^{\mathbf{3 2}}$.

W ,człowieku bez ciągłości” każdy z trzech ośrodków może dominować przez pewien okres czasu, aby następnie być nagle zdetronizowany przez inny. Nie dochodzi tutaj do jakiejś wewnętrznej walki, ale też nie istnieje ,pokojowa koegzystencja" ośrodków. Jest ich ciągłe, gwałtowne przemieszczanie się na pierwsze miejsce. Człowiek tego typu zdolny jest do szczerej i głębokiej skruchy, by za chwilę pałać żądzą zemsty. W fenomenie tym kryje się — zdaniem von Hildebranda - pewien element irracjonalny, a nawet demoniczny ${ }^{\mathbf{3}}$.

Wszystkie te wyliczone powyżej konfiguracje ośrodków są jedynie pewnymi schematami poznawczymi; w rzeczywistości bowiem ich układ może ulegać zmianom, rozmaitym kombinacjom itd. W każdym jednak wypadku współistnienie trzech ,ja” przedstawia się jako stan rzeczy domagający się przemiany. Jawi się bowiem jako oczywiste, że dominacja ośrodków negatywnych jest moralnie negatywna, a dominacja ośrodka pozytywnego jest pozytywna moralnie.

Po uprzednim zidentyfikowaniu źródeł ślepoty na wartości możemy teraz dostrzec, że droga ku należytemu poznawaniu wartości moralnych wieść musi poprzez przezwyciężenie ośrodków negatywnych. W jaki sposób winno siẹ to dokonać?

\section{WSPÓEZALEŻNOSĆ BYTU MORALNEGO OSOBY i POZNANIA WARTOSCI}

Droga ku panowaniu ,ja miłującego" rozpoczyna się od ukonstytuowania przez osobę podstawowej intencji moralnej (moralische Grundintention), polegające na świadomym i stałym ukierunkowaniu woli ku dobru moralnemu; jest to wola bycia moralnie dobrym ${ }^{34}$. Intencja ta wykracza zawsze ponad aktualny stan moralny, prowadząc osobę ku coraz

${ }^{31}$ Por. IG, s. $87-90 ; M$, s. $242-243$.

32 Różne formy idolatrii moralnej von Hildebrand analzuje szerzej w IG, s. 13-188.

${ }^{33}$ Por. E, s. 437.

84 Por. SEW, s. $450 ; E$, s. 267. 
to wyższym poziomom moralności. Podstawowa intencja moralna rodzi się w odpowiedzi na apel fundamentalnej wartości jaką jest dobroć moralna; stanowi ona sam rdzeń dobrej woli ${ }^{35}$. Intencja ta jawi się zatem jako owoc odpowiedzi na wartość. Jeśli tak, to suponuje ona poznanie wartości, to zaś z kolei zakłada pewien poziom moralnego bytu osoby (widzieliśmy, że człowiek zdominowany przez pychę i pożądliwość jest aksjologicznie ślepy). Powracamy zatem do naszego początkowego problemu; wiemy już jednak, że rozwiązanie musi iść drogą różnych stopni moralnego bytu osoby. Zapytajmy więc z jakiego gruntu moralnego może zrodzić się ta podstawowa odpowiedź na wartość. Innymi słowy: jakie jest konieczne minimum warunków moralnych, ażeby można było dać taką odpowiedź, a wcześniej jeszcze, aby można było poznać podstawową wartość dobroci moralnej?

Minimum takie obecne jest - zdaniem von Hildebranda - w fundamentalnym nastawieniu (Grundeinstellung) człowieka ${ }^{36}$ na świat wartości moralnych. Osoba ludzka jako taka zdolna jest do uchwycenia podstawowej wartości dobroci i antywartości zła moralnego. Fundamentalne nastawienie osoby nie zakłada żadnego uprzedniego postrzeżenia i zrozumienia poszczególnych typów wartości; jest ono dane osobie ludzkiej jako takiej. W tym miejscu ,protomoralnym” — jak moglibyśmy je nazwać — osoba może uformować podstawową intencję moralną, albo też może utkwić w mieszaninie dobra i zła, którą von Hildebrand nazywa ,umiejscowieniem podstawowym" (Grundstellung) ${ }^{37}$. Rozwój moralny osoby zależał będzie od modalności jej podstawowej intencji moralnej ${ }^{88}$. Jeśli przybierze ona kształt nieorganiczonego oddania się wszelkiemu dobru moralnemu, to stworzone zostaną odpowiednie warunki do osiągnięcia najwyższych poziomów bytu moralnego. Przeciwnie, ograniczona dobra wola stworzy dogodny grunt dla powstania rozmaitych typów „ludzi kompromisu" ${ }^{89}$. Osoba, która uformowała nieograniczoną podstawową intencję moralną i wciela ją w życie, nie tylko faktycznie dezaprobuje swoje „umiejscowienie podstawowe”, ale dąży zarazem do przekształcenia go w ,zasadniczą postawę moralną" (moralische Grundhaltung), tzn. w stan, w którym całą wolą przylega do tej intencji ${ }^{40}$. W praktyce oznacza to rozpoczęcie długotrwałego procesu przemiany moralnej poprzez działanie moralnie dobre i formułowanie partykularnych intencji moralnych.

Od stopnia przekształcenia ,umiejscowienia podstawowego” w ,zasadniczą postawę moralną" zależało będzie poznawanie poszczególnych

35 Por. $M$, s. $21-23$.

36 Por. SEW, s. 595.

37 Por. SEW, s. 550, 559.

38 Por. SEW., s. 564. $31-38$.

s9 Opisy różnych typów przeciętności moralnej znaleźć można w SKS, s.

40 Por. SEW, s. 560. 
typów wartości. Dla uzyskania konstytutywnej zdolności widzenia konieczny będzie wyższy stopień panowania ,ja miłującego" aniżeli dla czysto przypadkowego postrzegania wartości moralnych. Znajomość (Kennen) wartości zakładać będzie jeszcze wyższy poziom bytu moralnego. a czucie nie będzie możliwe bez posiadania odpowiedniej cnoty (im doskonalsza będzie cnota, tym głębsze będzie czucie wartości) ${ }^{41}$. Zdolność subsumcji wartości wymagała będzie uczynienia $z$ podstawowej intencji moralnej organicznej zasady życia etycznego.

Okazuje się zatem, że moralny byt osoby ludzkiej stoi zawsze u podstaw poznania wartości. Poszczególnym stopniom tego bytu odpowiadają różne sposoby poznawania wartości. Jedynie w sferze aktów relacja jest odwrotna: tutaj poznanie wartości jest warunkiem dobra działania. Nie jest to warunek wystarczający, lecz konieczny; wystarczającym staje się - zdaniem von Hildebranda - jedynie w tych przypadkach, kiedy w grę wchodzi szczególnie głębokie czucie wartości. Jest bowiem rzeczą niemożliwą, by tak głębokiemu czuciu nie odpowiadała żadna odpowiedź na wartość ${ }^{42}$.

Zaznaczyliśmy uprzednio, że im wyższa wartość wchodzi w rachubę, tym częstsze są przypadki ślepoty. Możemy obecnie dodać, że poznanie wyższych wartości wymaga zawsze pewnego „więcej” w bycie moralnym osoby ludzkiej ${ }^{43}$.

\section{UWAGI KOÑCOWE}

W przedstawionej - w głównym tylko zarysie — von Hildebranda koncepcji poznania wartości moralnych, dostrzec możemy ogólne założenia jego teorii poznania i aksjologii. W dziedzinach tych korzystał on wiele, co sam otwarcie przyznawał, z filozoficznych odkryć M. Schelera, krytycznie je rozwijając. Nie miejsce tutaj na przeprowadzanie porównań stanowisk filozoficznych obydwu fenomenologów, na uwypuklanie podobieństw czy daleko nieraz idących różnic. Trwałym dziedzictwem Schelera w filozofii von Hildebranda jest zwrócenie uwagi na konieczność posiadania pewnych pozateoretycznych dyspozycji dla wszelkiego adekwatnego poznania. Widzieliśmy jak doniosłą rolę odgrywa ,ja miłujące" - które gdzie indziej von Hidebrand nazywa również ,,ja pokornym i pełnym szacunku" ${ }^{44}$ - w poznaniu wartości moralnych. Odwrotnie, pycha i pożądliwość prowadzić mogą aż do totalnej ślepoty na wartości.

\footnotetext{
41 Por. SEW, s. 598.

42 Por. SEW, s. 601.

43 Por. $M$, s. 83.

44 Por. E, s. 425.
} 
Czy w tej sytuacji, ślepoty totalnej, możliwe jest nawrócenie, „przejrzenie"?

Von Hildebrand wspomina wprawdzie o doniosłości wzorca i prawowitego autorytetu moralnego $\mathrm{w}$ procesie uzdrawiania ze ślepoty (jeśli niewidzący chce uzyskać wzrok aksjologiczny, to powinien pozwolić prowadzić się komuś, kto już widzi) ${ }^{45}$. Tego rodzaju postępowanie możliwe jest jednak w przypadkach ślepoty częściowej i subsumcji. Powierzenie się czyjemuś autorytetowi zakłada już bowiem poznanie jego wartości, a także wartości samego powierzenia się. Jak więc przedstawia się sprawa w wypadku ślepoty totalnej, zwłaszcza ,ślepoty wrogości”? Wydaje się, że tego rodzaju ślepota może mieć miejsce tylko w wyjątkowych wypadkach. Czyż subtelne światło dobra nie jest w stanie przebić się nawet przez grubą warstwę pychy i pożądliwości, aby dotrzeć do wnętrza,,ja miłującego"? Nie chcemy przez to powiedzieć, że ślepotę totalną należy praktycznie wykluczyć. Być może właśnie na owej upartej walce,,ja pysznego" ze światłem polega grzech, ,który sprowadza śmierć" i wobec którego nawet modlitwa zdaje się być bezskuteczna (por. $1 \mathrm{~J}$ 5,16)?

Von Hildebrand w swych analizach fenomenologicznych zajął się głównie moralnymi uwarunkowaniami poznania wartości i ślepoty na nie. Tylko mimochodem wspominał o możliwości ślepoty niezawinionej, będącej np. wynikiem wychowania w błędnej tradycji moralnej, wpływu środowiska kulturowego czy etosu jakiejś wspólnoty ${ }^{48}$. Również bez wchodzenia w dokładne analizy mówił o możliwości innego, nie intuicyjnego poznania wartości. „Każde poznanie (Erkennen) zasadza się ostatecznie na ujęciu poznawczym (Kenntnisnahme), jakkolwiek do poznania pewnych stanów rzeczy możemy dojść poprzez wnioskowanie, bez ich wyraźnego ujęcia poznawczego. Widząc dym mogę dojść do poznania, że w pewnym miejscu znajduje się ogień, chociaż samego ognia nie postrzegam. Tak też mogę - być może — na podstawie wcześniejszych poznawczych ujęć wartości, dojść na drodze wnioskowania, do poznania, że kłamstwo jest niesłuszne, że jakieś określone zachowanie jest słuszne bądź niesłuszne, jednak bez rzeczywistego naocznego uchwycenia czy 'czucia' wartości lub antywartości" ${ }^{47}$. Temu rodzajowi poznania wartości von Hildebrand nie przyznawał jednak żadnej roli w życiu moralnym człowieka. Jest to pewne ograniczenie jego etyki; ograniczenie, które staje się może bardziej wyraźne dzisiaj, kiedy pojawiają się złożone problemy związane np. z doświadczeniami nad przekazywaniem życia ludzkiego czy $\mathrm{z}$ organizacją życia międzynarodowego. Nie zawsze bowiem można w tych dziedzinach dojść do intuicyjnych, bezpośrednich ujęć

45 Por. SEW, s. $574,599,602$; SKS, s. 209-229; IG, s. $28,388$.

${ }^{46}$ Por. E, s. $115-116$; SKS, s. 137 ; IG, s. $24-25,28-29$.

$47 \mathrm{SEW}$, s. 468. 
poznawczych wartości czy antywartości; nie zawsze też brak jednoznacznych rozwiązań będzie tutaj skutkiem ślepoty na wartości, tym bardziej ślepoty zawinionej. Ograniczenie powyższe wypływa - jak sądzimy z von Hildebranda metafizyki wartości moralnych. Jest to jednak osobny temat.

\author{
LA CONOSCENZA DEI VALORI MORALI \\ SECONDO DIETRICH VON HILDEBRAND
}

\title{
Ri a s s u n to
}

L'articolo affronta il problema dei nessi essenziali tra l'essere morale della persona umana e la conoscenza dei valori morali. Più precisamente, ci si interroga - seguendo le orme di D. von Hildebrand - sui differenti gradi qualitativi dell'essere morale, come condizioni necessarie di una percezione del valore adeguatamente differenziata. Nel quadro delle analisi vengono individuati il fenomeno della ,cecità ai valori", nonché le sue radici, ossia due centri negativi nella persona: l'orgoglio e la concupiscenza. Il centro positivo costituisce il cosiddetto "l'io amante". Dalle analisi emerge che l'essere morale sta sempre alla base della conscenza dei valori. Il suo strato più profondo è dato assieme alla posizione fondamentale della persona, nella quale essa è orientata onticamente al mondo dei valori. Ad ogni strato morale è legato un corrispettivo tipo della conscenza dei valori.

Nella parte critica dell'articolo vengano messe in rilievo alcune insufficenze della concezione di von Hildebrand, che - secondo parere dell'autore - risultano dalla sua metafisica dei valori. 